Missio Ecclesiae
ISSN 2086-5368 (Print)
ISSN 2086-5368 (Online)
https://jurnal.i3batu.ac.id/index.php/me
Vol.10, No.1, pp. 68-82, 2021

\title{
Subordinasionisme Allah Tritunggal Dalam Pengajaran Pluralisme
}

\author{
Fanny Yapi Markus Kaseke ${ }^{a}$ \\ ${ }^{a *}$ Sekolah Tinggi Teologi Ebenhaezer, Yapimarkus73@gmail.com
}

\section{INFO ARTIKEL}

Sejarah Artikel:

Diterima: April 2021

Direvisi: April 2021

Disetujui: April 2021

Dipublikasi: April 2021

Kata Kunci:

Subordinasionisme,

Allah Tritunggal,

Pluralisme

Keywords:

Subordinasionism, The

Triune God, Pluralism

\begin{abstract}
ABSTRAK
Subordinasionisme Allah Tritunggal Dalam Pengajaran Pluralisme. Artikel ini mengulas tentang salah satu ajaran dari sekian ajaran yang beragam tentang Allah Tritunggal, yakni subordinasionisme. Kemudian hari, ajaran subordinasionisme digunakan kalangan pluralis untuk menyokong pendapat mereka. Tujuan artikel ini adalah menganalisa ajaran tersebut. Metode yang digunakan dalam penelitian ini adalah metode penelitian theologia filosofika dengan pendekatan apologetika. Pendekatan apologetika yang digunakan adalah dengan apologetika presuposisional. Subordinasionisme dalam Allah Tritunggal sebenarnya tidak ada. Perbedaan yang terlihat dalam Allah Tritunggal sebenarnya hanya menyangkut fungsi tiga pribadi Allah yang berbeda-beda dalam hubungan dengan ciptaan (opera ad extra). Konsep subordinasi yang dikemukakan kaum pluralis sebenarnya hanyalah upaya untuk "menganulir" ajaran Kristen bahwa Allah Tritunggal yang esa itu terdiri dari tiga pribadi (hypostasis), yakni Allah Bapa, Allah Anak (yaitu Yesus Kristus), dan Allah Roh Kudus. Karena apabila Yesus Kristus dapat dibuktikan bukan Allah, maka itu berarti ajaran pluralisme mengenai adanya kebenaran dalam semua agama adalah benar, dan sebaliknya ajaran Kristen (ortodoksi) keliru. Pluralisme bukan sekedar konsep sosiologis, melainkan lebih merupakan "doktrin" theologis yang didasarkan pada relativisme yang bersumber pada pandangan dunia atomis, maupun pandangan oseanis, sedangkan keunikan dan finalitas Kristus dianggap sebagai sebuah mitos yang perlu ditinggalkan.
\end{abstract}

\section{ABSTRACT}

Subordinasionisme Allah Tritunggal Dalam Pengajaran Pluralisme. This article reviews one of the various teachings about the triune God, namely subordinationism. Later on, the teaching of subordinationism were used by pluralists to support their opinions. The purpose of this article is to analyze the teaching. The method used in this study is the philosophical theological research method with an apologetic approach. The apologetics approach used is presuppositional apologetics. Subordinationism in the Triune God does not really 
exist. The difference seen in the Triune God is actually only concerned with the functions of the three different persons of God in relation to creation (opera ad extra). The concept of subordination proposed by pluralists is actually just an attempt to "annull" Christian teachings that the one Triune God consists of three persons (hypostasis), namely God the Father, God the Son (ie Jesus Christ), and God the Holy Spirit. Because if Jesus Christ can be proven not God, then that means the teachings of pluralism regarding the existence of truth in all religions are true, and vice versa Christian teachings (orthodoxy) are wrong. Pluralism is not just a sociological concept, but rather a theological "doctrine" based on relativism which is based on the atomic worldview, or oceanic view, while the uniqueness and finality of Christ are considered as a myth that needs to be abandoned.

\section{PENDAHULUAN}

Pada zaman berkembangnya Theologia Modern, berkembang juga Theologia Pluralisme yang dikembangkan oleh sebagian Theolog Kristen, sebagai antisipasi kemajemukan agama-agama yang ada di dunia. Theologia Pluralisme ini berbeda pengajarannya dari Theologia Tradisional dan yang diyakini Gereja Tuhan selama berabadabad (yang juga menjadi posisi penulis), (Carson 1996).

Theologia Pluralisme dimulai dari semangat pencerahan dan perlawanan terhadap otoritas gereja dan agama tradisional, di mana Pluralisme pada tingkat filosofi gencar dikumandangkan oleh beberapa Theolog Kristen untuk mengapresiasi agama-agama di luar Kekristenan baik itu agama kitab atau wahyu (Yahudi, Islam) maupun agama-agama Timur lainnya seperti Hindu, Buddha dan Konfusianisme.(Hick, John and Knitter 1992)

Menurut kaum pluralis, hal yang sering terlihat sebagai akibat dari hidup bersama secara majemuk adalah bahwa: agama Kristen dalam upaya mengklaim kebenaran yang satu-satunya, akhirnya menjadi upaya penghakiman agama sehingga memutuskan hubungan antar agama. Alasan yang dikemukakan antara lain adalah, apabila berbicara tentang membangun jembatan kerjasama antar agama, benturan utama yang paling sering menghambat kebersamaan agama-agama dalam kesatuan adalah berhubungan dengan ajaran Trinitas dalam agama Kristen. Sumartana menulis "dalam rangka ajaran Kristen, tentu kita akan segera bertemu dengan ajaran Trinitaris, yaitu bagaimana kita mengungkapkan relevansi dari ajaran tentang Tuhan Bapa, Tuhan Anak, Tuhan Roh Kudus itu dan dalam menilai harga agama-agama non Kristen ...Kristologi kita anggap sebagai bagian dari keunikan partikulariat, sedang Theologia bagian dari universalitas. Soalnya adalah bagaimana kita menafsirkan Kristologi secara baru sehingga mampu memberi tempat bagi agama-agama? Secara umum bisa kita katakan bahwa Kristologi yang ada tidak dirumuskan dalam konteks pluralisme agama-agama seperti yang sekarang ini'.(Sumartana 1999)

Dari pernyataan Sumartana ini sangat jelas terasa adanya usaha untuk merumuskan suatu doktrin Trinitas dan Kristologi yang baru supaya pertemuan dengan agama-agama boleh dicapai, sehingga yang dibutuhkan sebenarnya bukan Kristologi agama-agama, tetapi Theologia Agama-Agama (theologia religionum) yang intinya adalah dialog dan kolaborasi antar agama. Sementara itu Sinaga menyatakan: "Pertemuan antar agama mengakibatkan berlakunya hukum alam, harus sanggup menyesuaikan diri dengan keadaan alam apabila ingin survive." Lebih lanjut Sinaga menegaskan "kalau agama tersebut mau tetap survive dalam konteks baru ini, ia harus mampu memberi respons keterbukaannya terhadap keadaan pluralisme tersebut, seperti seorang penari yang tidak boleh menari sendirian lagi, tetapi harus mau bergerak seturut dengan irama bersama dan mampu memberi jawaban terhadap 
gerak (bahkan kreatifitas) teman menarinya, agar ia tidak tersandung jatuh ataupun menginjak kaki penari lainnya, lalu terpaksa dikeluarkan dari arena tarian karena mendesakkan gaya tertentu dan terkesan sewenang-wenang.(Sinaga 1999)

Siapakah yang dimaksudkan Sinaga dengan yang mendesakkan gaya tertentu dan sewenang-wenang? Walaupun pernyataannya nampaknya berlaku secara umum, namun jelas di sini bahwa yang dimaksudkannya adalah agama Kristen. Beranjak dari pemikiran ini, kaum pluralis mencoba merubah ajaran tentang kebenaran mutlak di dalam Kristus Yesus lewat usaha merumuskan kembali doktrin tentang Allah Tritunggal.(Pannikar 2001)

Dengan latar belakang inilah maka diangkat kembali suatu konsep tentang ketidaksetaraan Kristus (sebagai pribadi kedua Allah Tritunggal) dengan Bapa (sebagai pribadi pertama Allah Tritunggal), baik dari segi esensi, status maupun tingkatan, inilah yang dikenal dengan Subordinasionisme. Subordinasionisme yang dimaksudkan di sini perlu dibedakan dengan jelas dengan doktrin ortodoks yang menjelaskan tentang hubungan opera ad intra dan opera ad extra antara Allah Bapa dan Allah Anak, bahwa sang Anak (pribadi kedua Allah Tritunggal) secara kekal "subordinasi" terhadap Bapa (pribadi pertama Allah Tritunggal) dalam hal peran atau fungsi.

Beberapa pernyataan kaum pluralis tentang subordinasionisme nampak dalam dua tulisan berikut. Pertama, Yewangoe, mengangkat tulisan Paul Knitter yang menyatakan bahwa terdapat suatu subordinasi antara Yesus dengan Allah yang dicatat dalam Perjanjian Baru, "Kristosentrisme Perjanjian Baru tidak kehilangan teosentrisme asli Yesus. Yesus tidak pernah menggantikan Allah. Bahkan dalam tiga teks di mana Yesus diproklamasikan sebagai Tuhan atau sebagai yang ilahi (Yoh.1:1; 20:28; Ibr.1:8-9), suatu subordinasi yang jelas senantiasa terlihat.(Yewangoe 2001) Berikutnya, Rakhmat, dalam salah satu tulisannya mengangkat istilah "subordinasionisme" untuk menjelaskan siapakah Anak Manusia dalam Injil Yohanes. Contoh ungkapan Rakhmat yang mengandung subordinasionisme antara Allah Bapa dan Allah Anak nyata dari penjelasannya, "Di dalam Injil Yohanes, subordinasi Anak Manusia dalam hubunganNya dengan Allah digambarkan dengan jelas".(Rakhmat 1996)

Pengajaran subordinasi ini demikian mendukung pengajaran kaum pluralis yang berpegang pada ajaran bahwa Yesus Kristus hanyalah ciptaan Allah.

Tulisan ini memiliki aspek kebaruan (novelty) karena belum ada satu penulispun yang menghubungkan antara ajaran subordinasionisme dalam Allah Tritunggal dengan teologi pluralisme. Maka tulisan ini adalah suatu upaya membangun teori baru. Banyak tulisan yang mengulas tentang subordinasionisme an sich, atau menghubungkannya dengan konteks praktis tertentu misalnya tulisan Cortez, Origen's Trinitarian Theology; tulisan Tinkham Jr., Neo Subordinationism: The Alien Argumentation in the Gender Debate; tulisan Cary, The New Evangelical Subordinationism: Reading Inequality Into the Trinity; dan tulisan Bilal BAS, Orthodoxy of Origen of Alexandria's Trinitarian Doctrine: Is His Theology Arian or Nicene? Demikian juga tulisan-tulisan mengenai teologi pluralism ada sangat banyak, di antaranya tulisan Dupuis, Toward a Christian Theology of Religious Pluralism; tulisan Olawoyin, Varities of Religious Pluralism; Siregar, Pluralism and Religious Tolerance in Indonesia: An Ethical Theological Review Based on Christian Faith Perspectives; tulisan Baptista, Theology Facing Religious Diversity: The Perspective of Latin American Pluralist Theology; serta tulisan McGrath, The Challenge of Pluralism for the Contemporary Christian Church, dan masih banyak tulisan lainnya, tidak satupun yang menghubungkan antara Subordinasionisme dengan Pluralisme, maka penulis meyakini bahwa tulisan ini adalah yang pertama kali ditulis. 


\section{KAJIAN LITERATUR}

\section{Ajaran Alkitab Tentang Trinitas}

Alkitab adalah sumber pengajaran Kristen, dan merupakan sumber utama yang membahas tentang Trinitas atau Allah Tritunggal. Ada beberapa pendapat dari kalangan bidat bahwa Alkitab sebenarnya tidak mengajarkan tentang Trinitas, karena istilah itu secara eksplisit tidak terdapat dalam Alkitab (Tong 1990), akan tetapi Alkitab dengan tegas mengajarkan hal ini, dan bahwa kata Trinitas digunakan untuk meringkaskan pengajaran Alkitab tentang Allah yang satu tetapi memiliki tiga pribadi (Grudem 1994). Ichwei G. Indra mengatakan tentang adanya sejumlah ayat Alkitab yang dianggap menjadi petunjuk bahwa Allah yang satu dan esa memperkenalkan diriNya sebagai Allah Tritunggal (Indra 2000). Ajaran tentang Trinitas sangat penting bagi Kekristenan, karena ajaran tersebut menyangkut siapakah Allah, seperti apakah Allah, bagaimana Allah berkarya dan bagaimana Allah didekati (Erickson 1983).

Dalam Alkitab terdapat beberapa ayat yang menunjukkan kejamakan Allah. Misalnya dalam Kejadian 1:26, ketika Allah berfirman: "Baiklah Kita menjadikan manusia menurut gambar dan rupa Kita." Ayat ini mengindikasikan adanya kejamakan pribadi dalam Allah. Hal yang sama terdapat dalam Kejadian 11:7: "Baiklah kita turun dan mengacaubalaukan di sana bahasa mereka" juga menegaskan bahwa terdapat kejamakan dalam keallahan. Maka ketika Allah berbicara mengenai diriNya sendiri dengan kata ganti bentuk jamak (Kej.1:26; 3:22; 11:7; Yes.6:8) dan kata kerja bentuk jamak (Kej.1:26; 11:7), agaknya itu menunjukkan adanya pribadi-pribadi yang berbeda, walaupun hanya menunjukkan kejamakan bukan khusus Trinitas (Ryrie 1986). Oliver Buswell mengutip katekismus Westminster mengemukakan bahwa ada tiga pribadi dalam keallahan, yaitu Bapa, Anak dan Roh Kudus, dan ketiganya sama dalam substansi, seimbang dalam kuasa dan kemuliaan (Buswell 1978).

Wayne Grudem mengemukakan bahwa ada peran utama masing-masing pribadi dalam penciptaan dan penebusan, yakni Allah Bapa mengucapkan kata-kata kreatif untuk mewujudkan alam semesta, kemudian Allah Anak, melaksanakan ketetapan kreatif ini, selanjutnya Roh Kudus juga aktif dalam cara yang berbeda, dalam bergerak atau melayang di atas permukaan air (Kej. 1:2) (Grudem 1994). Peran-peran tersebut tidak dapat dibalik; artinya sang Bapa tidak melakukan peran sang Anak dan Roh Kudus, demikian juga sang Anak tidak melakukan peran sang Bapa dan Roh Kudus, atau Roh Kudus melakukan peran sang Bapa dan sang Anak (Grudem 1994).

Setiap pribadi Trinitas mempunyai semua atribut Allah, dan tak satupun dari pribadipribadi itu mempunyai beberapa atribut yang tidak dipunyai oleh pribadi-pribadi yang lain. Tetapi jika tiap-tiap pribadi adalah sepenuhnya Allah dan memiliki semua keberadaan Allah, tidak dimaksudkan bahwa perbedaan pribadi itu adalah suatu bentuk penambahan atribut yang ditambahkan pada keberadaan Allah. Di lain pihak harus dikatakan bahwa pribadipribadi tersebut nyata, bukan hanya cara pandang yang berbeda-beda dari suatu keberadaan Allah (pandangan seperti ini adalah ajaran modalisme atau sabelianisme (Grudem 1994).

\section{Trinitas dan Kristologi Dalam Injil Yohanes}

Injil Yohanes dimulai dengan ayat-ayat Kristologi yang sangat jelas di dalam Alkitab (Waaler 1993). Yohanes memulai Injilnya dengan sang Firman, yaitu Kristus: "Pada mulanya adalah Firman"(Yoh.1:1). Hanya Yohanes yang mengatakan Yesus sebagai Firman (logos) (McCready 1997). Menurut Ridderbos, prolog Injil Yohanes, secara khusus ayat 1-5 yang merupakan eksposisi dari Kejadian 1:1-5, memberi dasar pada peristiwa kedatangan Kristus kedunia, dan bahwa kata "pada mulanya" dalam Yohanes 1 memiliki arti yang lebih luas dari pada kata "pada mulanya" dalam Kejadian 1 (Ridderbos 1991). 
Hubungan antara Firman dengan Bapa dapat dilihat pada penggunaan kata pros, "bersama-sama," dalam Yohanes 1:1. Henry Alford menyatakan bahwa kata pros ("bersama-sama") memberikan pengertian bahwa ada satu pribadi yang berbeda yaitu sang Firman (logos), tetapi sang Firman tersebut satu substansiNya dengan Allah (Bapa) (Alford 1958). Kesatuan antara sang Firman dengan Bapa dengan tegas dikemukakan Yesus dalam Yohanes 10:30, "Aku dan Bapa adalah satu." Kata "satu" dalam bahasa Yunani adalah dalam bentuk neuter, bukan bentuk maskulin (Morris 1986). Kesetaraan Firman dengan Bapa nampak dalam perkataan Yesus pada pasal 5 ayat 17 bahwa: "BapaKu bekerja sampai sekarang, maka Akupun bekerja juga" (ho pater mu eos arti ergasetai, kago ergasomai) (Alford 1958).

\section{Subordinasionisme}

Walter Elwell mendefinisikan subordinasionisme adalah sebuah pengajaran yang memberikan keadaan yang lebih rendah dari segi keberadaan (being), status dan peran sang Anak atau Roh Kudus dalam Trinitas (Walter A. Elwell (ed.) 1997). Sedangkan Erickson mendefinisikan subordinasionisme sebagai ajaran yang menyatakan bahwa dalam esensi dan status, sang Anak lebih rendah dari Bapa, atau Roh Kudus lebih rendah dari Bapa dan Anak.(Millard J. Erickson 1995)

Munculnya konsep subordinasi Anak terhadap Bapa terkait erat dengan perkembangan perumusan ajaran Allah Tritunggal atau Trinitas. Sepanjang sejarah Kristen, masalah bagaimana mempertemukan pengalaman akan keilahian dalam tiga bentuk (Bapa, Anak dan Roh Kudus) dengan prinsip keesaan Tuhan (monoteisme) telah menjadi bahan kajian dan perenungan yang sangat mendalam bagi orang-orang Kristen. (Hupudiyo 2003) Berbagai paham tentang Trinitas itu berpusat pada perbedaan paham tentang tokoh Yesus. Menurut Injil Yohanes, keilahian Yesus adalah titik awal untuk memahami pribadi dan karyanya. Yesus adalah keilahian yang telah ada sebelum ruang dan waktu ini tercipta, dan yang turun ke dunia (berinkarnasi) untuk menebus yang berdosa. Di lain pihak, Injil Markus tidak berangkat dari teologi inkarnasi, melainkan memahami baptisan Yesus di sungai Yordan sebagai pengangkatan manusia Yesus ke dalam kedudukan Putra Allah (sonship of God), yang terjadi dengan turunnya Roh Kudus dalam wujud burung merpati. Jadi sampai di sini sudah dua pendekatan yang berbeda. (Hupudiyo 2003)

Perbedaan-perbedaan paham ini menyebabkan munculnya banyak spekulasi pengajaran tentang Trinitas. Salah satu spekulasi yang muncul, karena dipengaruhi oleh filsafat Neo-Platonisme. Di dalam filsafat Neo-Platonisme ini, baik nous maupun ide alam semesta disebut hypostasis dari Allah yang transenden. (Hupudiyo 2003) Pada abad ke-3 M orang mulai sadar bahwa upaya memahami misteri Trinitas menurut teori hypostasis NeoPlatonik tidak memuaskan dan malah menimbulkan pertanyaan-pertanyaan baru. Puncak di mana kesulitan itu mencuat secara teologis dan eklesiastik ke permukaan secara mencolok adalah apa yang disebut "kontroversi Arius." (Hupudiyo 2003) Arius termasuk aliran teologi Antiokhia, yang menekankan historisitas dari manusia Yesus. Dalam teologinya, Arius mempertahankan pemahaman formal tentang keesaan Allah, persis seperti ditekankan oleh doktrin Tauhid dalam Islam, dan deklarasi "Shema" dalam agama Yahudi. Di dalam mempertahankan keesaan Allah itu, Arius terpaksa menyanggah kesamaan antara hakikat Putra dan Roh Kudus di satu pihak dengan hakikat Allah Bapa di lain pihak. (Hupudiyo 2003) Pengajaran-pengajaran Arius menyebabkan orang Kristen berada pada suatu dilema: kalau di dalam dikotomi Pencipta-ciptaan, Yesus berada di pihak ciptaan, padahal ciptaan memerlukan penebusan, bagaimana Yesus bisa menebus dunia? Jadi, secara keseluruhan Gereja Kristen menolak upaya formal untuk mempertahankan keesaan Allah yang dipelopori Arius (Hupudiyo 2003) 
Juru bicara utama dari pihak ortodoksi Gereja adalah Athanasius dari Aleksandria. Athanasius mengemukakan pengajaran yang bertolak-belakang dengan pengajaran Arius. Athanasius beranjak dari realitas manusia yang membutuhkan keselamatan, dimana keselamatan itu hanya terjadi kalau terjadi penebusan manusia dari dosa. (Hupudiyo 2003) Dewan Nicea dibentuk tahun 325 untuk memecahkan pertentangan pandangan ini. Persoalan atau kontroversi ini diperjelas agar pembahasannya lebih mudah. Pengikut Arius menolak pandangan tentang penciptaan kekal (penciptaan yang bebas dari dimensi waktu), sementara Athanasius mempertahankannya. Pengikut Arius mengatakan bahwa Anak diciptakan dari tidak ada, sementara Athanasius mengatakan bahwa Dia diciptakan dari esensi Bapa. Pengikut Arius berpendapat bahwa Anak tidak sama substansinya dengan Bapa sementara Athanasius berpendapat bahwa Anak adalah homoousios dengan Bapa. (Jacobs 2000) Setelah melalui perdebatan yang panjang, akhirnya pihak Athanasius berhasil memenangkannya. Dewan Nicea yang terdiri dari 318 Uskup akhirnya mengeluarkan pernyataan yang dikenal sebagai kredo Nicea. (Jacobs 2000)

Sehabis konsili Nicea, bukan berarti kontroversi itu pun berakhir. Kontroversi Arius ini berlangsung selama 60 tahun lagi. Arius dan kawan-kawan berjuang terus dan berhasil mempengaruhi Kaisar yang memerintah. Akibatnya, Athanasius sempat diasingkan sampai lima kali. Demikianlah, Kaisar demi Kaisar silih berganti, yang satu mendukung Arianisme, dan yang lain mendukung Kredo Nicea. (Hupudiyo 2003) Kaisar Theodisius I kemudian mengadakan suatu konsili di Konstantinopel (381) dihadiri 150 uskup ortodoks gereja Timur. Hasil utama konsili adalah pengakuan iman yang baru yakni kredo Konstantinopel. (Jacobs 2000)

Rumusan Trinitas yang final adalah apa yang dikenal sebagai Kredo Athanasius (sekitar tahun $500 \mathrm{M}$ ), yang sebetulnya bukan ditulis oleh Athanasius, karena ia wafat tahun 373 M. Kredo itu pada dasarnya menekankan "una substantia-tres personae" (satu zat, tiga pribadi). Rumusan ini diterima sebagai akidah resmi Gereja Katolik dan beberapa Gereja Protestan. (Hupudiyo 2003)

\section{METODE PENELITIAN}

Metode yang digunakan dalam penelitian ini adalah metode penelitian theologia filosofika dengan pendekatan apologetika (Lumintang 2016). Pendekatan apologetika yang digunakan adalah dengan apologetika presuposisional. Metode ini dipilih untuk mempertahankan kemurnian ajaran Kristen yang bersumber dari Alkitab dan yang dirumuskan oleh bapa-bapa gereja. Dalam waktu yang sama juga menyerang ajaran yang menyimpang dari ajaran Kristen, dalam hal ini subordinasionisme dalam pengajaran para tokoh pluralisme. Mula-mula penulis mempelajari isi ajaran subordinasi kalangan pluralis, kemudian menganalisa ajaran tersebut berdasarkan ajaran Alkitab dan tradisi teologi Injili. Dalam menganalisa ajaran tersebut, penulis sudah memiliki beberapa presuposisi yang menegaskan posisi penulis sebagai seorang teolog Injili. Adapun ajaran subordinasi kaum pluralis yang akan dianalisa adalah yang dikemukakan oleh Ioanes Rakhmat, dan Tom Jacobs. 


\section{HASIL DAN PEMBAHASAN}

\section{Subordinasionisme Kaum Pluralis}

Berikut akan dikemukakan dua ajaran tokoh pluralis mengenai adanya subordinasionisme dalam Allah Tritunggal.

\section{a. Pandangan Ioanes Rakhmat Tentang “Logos” Dalam Injil Yohanes}

Dalam tulisannya yang berjudul: “Kristologi 'Anak Manusia' Di Dalam Injil Yohanes Dan Monoteisme Yahudi", Ioanes Rakhmat mengangkat suatu pertanyaan: "Apakah Injil Yohanes mengetengahkan suatu pandangan diteisme bahwa ada Dua Penguasa di sorga, yaitu sang Firman (ho Logos) dan Allah (ho Theos), atau 'Anak Manusia' yang datang dari sorga dan Allah. Apakah dengan memakai ungkapan dari Wahyu Yohanes, di sorga memang ada Dua Takhta, yaitu takhta Allah dan takhta Anak Domba (22:1)"? (Rakhmat 1996)

Berusaha menjawab pertanyaannya ini, Rakhmat mencoba membandingkan isi Injil Yohanes dengan latar belakang penulisan Injil tersebut, yang menurutnya berasal dari lingkungan Yahudi ortodoks. Menurutnya, mazhab atau aliran pemikiran yang melahirkan Injil ini berusaha tetap mempertahankan monoteisme Yahudi, dengan "Pengakuan Imannya" (Syema, Ulangan 6:4-6). Persoalan muncul karena dalam isi Injil Yohanes, ada "tokoh sorgawi" lain (Logos) yang datang ke dalam dunia dan disamakan dengan Allah sendiri (misalnya dalam Yoh.1:1c; 5:17-18; 10:33). Usaha untuk mengantisipasi Injil Yohanes dengan "Kristologi dari atas," supaya tidak terjatuh dalam paham diteisme tetapi tetap menempatkannya dalam bingkai monoteisme Yahudi, salah satunya ditempuh Rakhmat dengan konsep subordinasi.(Rakhmat 1996)

Konsepnya dimulai dengan melihat hubungan Allah dengan Anak Manusia sebagai suatu hubungan dalam rangka tugas pengutusan. Allah mengutus dan Anak Manusia diutus. Anak Manusia datang bukan karena kehendakNya sendiri, tetapi karena diutus (Yoh.7:28) untuk melakukan kehendak Allah yang mengutusNya. Yang mengutus tentu saja berkedudukan lebih tinggi dari yang diutus, atau yang diutus berkedudukan lebih rendah dari yang mengutus. Selanjutnya Rakhmat berkata, di dalam Injil Yohanes, subordinasi Anak Manusia dalam hubungannya dengan Allah digambarkan dengan jelas. Rakhmat mengambil beberapa bagian Injil Yohanes untuk memperkuat argumennya yaitu: Yohanes 5:19, menyatakan bahwa Anak tidak dapat mengerjakan sesuatu dari diriNya sendiri, jikalau Ia tidak melihat Bapa mengerjakanNya. Yoh.5:26 mengatakan bahwa Anak, meskipun mempunyai hidup di dalam diriNya sendiri, menerima hidup itu dari Allah. Yoh.5:30, Anak Manusia menghakimi, tetapi kuasa untuk menghakimi diterimaNya dari Allah (5:27). Dalam 5:30a dan 8:28 dikatakan bahwa Anak Manusia tidak dapat berbuat apa-apa dari diriNya sendiri; dan bahwa Ia tidak menuruti kehendak diriNya sendiri (5:30d). Anak Manusia tidak bersaksi mengenai diriNya sendiri, kesaksianNya itu tidak benar (5:31). Kesaksian sebenarnya mengenai diri Anak Manusia justru berasal dari "pekerjaan-pekerjaan" yang dilakukanNya yang diterimaNya dari Allah (5:36). Anak Manusia mengajarkan hal-hal yang Ia terima dari Allah (7:16; 8:26); dan Ia sendiri menerima pengajaran dari Allah (8:28). Ia diperintah oleh Allah untuk mengatakan apa yang Ia harus katakan dan sampaikan (12:49; 14:31; 15:15). Bahkan dikatakan bahwa Anak Manusia bukanlah "objek" kepercayaan; orang yang percaya kepadaNya bukanlah percaya kepadaNya tetapi kepada Allah yang mengutusNya (12:44). Bahkan, Allah adalah "tujuan hidup dari Yesus sendiri” (13:1; 14:12, $28 ; 16: 10,27 ; 17: 11,13 ; 20: 17)$.(Rakhmat 1996)

Menanggapi pandangan Raymond Brown bahwa Anak Manusia "hanya" lebih rendah dari Allah selama Ia dalam wujud manusia yang hidup di dunia, Rakhmat mengemukakan argumennya: Pertama, dalam Yohanes 7:28 dikatakan bahwa Anak Manusia sorgawi turun ke dunia karena diutus, bukan karena kehendakNya sendiri. Jadi, Anak Manusia ketika akan diutus dari kawasan sorgawi, telah menundukkan diriNya di hadapan Bapa. Penaklukan diri 
ini sudah dimulai di kawasan sorgawi; sebab bila tidak demikian tidak akan dinyatakan bahwa Anak Manusia turun dari atas bukan karena kehendakNya sendiri. Jadi harus dikatakan bahwa subordinasi pada dataran sejarah kemanusiaan adalah lanjutan dari subordinasi ontologis pada dataran adikodrati, subordinasi yang sudah ada sebelum Anak Manusia sorgawi memasuki kawasan duniawi. Kedua, pendapat Brown mempunyai konsekuensi logis bahwa sebelum Anak Manusia turun ke dalam dunia, di kawasan mana Ia menjadi lebih rendah dari Allah, adalah Allah sendiri atau setingkat dengan Allah. Padahal, menyangkut Anak Manusia, menurut Rakhmat, tidak satupun teks yang menyatakan bahwa Anak Manusia itu adalah Allah, baik sebelum Ia turun ke kawasan duniawi ataupun ketika Ia sudah berada di kawasan duniawi. Ketiga, di dalam menuturkan hidup dan karya Yesus di dalam dunia, Injil Yohanes memberikan gambaran baik anti-doketis maupun gambaran doketis, sehingga sama sekali tidak tepat bila dikatakan bahwa Injil Yohanes menggambarkan Anak Manusia lebih rendah dari Allah hanya selama pekerjaan-Nya di dalam dunia. Akhirnya, Ioanes Rakhmat menyimpulkan bahwa dengan adanya subordinasionisme ontologis yang dilanjutkan dengan subordinasionisme fungsional di dalam Injil Yohanes, penulis Injil ini memandang figur "Anak Manusia" sebagai "oknum" atau "hakikat" adikodrati yang lebih rendah kedudukannya dari Allah, yang dalam ketaklukanNya kepada Allah menerima tugas pengutusan untuk turun ke dalam dunia. Kedudukan Anak Manusia yang lebih rendah ini menyiratkan bahwa oknum Anak Manusia itu adalah oknum atau suatu hakikat adikodrati yang terpisah dari Allah.(Rakhmat 1996)

Sekalipun menyatakan adanya subordinasi antara Anak Manusia dan Allah, akan tetapi Rakhmat juga tidak mengesampingkan adanya bagian-bagian dalam Injil Yohanes yang dengan kuat menyatakan kesatuan Yesus dengan Allah. Rakhmat menafsirkan sendiri, bagaimana Injil Yohanes memahami gagasan tentang "kesatuan" ini. Beberapa nats seperti Yohanes 10:30, "Aku dan Bapa adalah satu", Yoh. 10:38d "Bapa di dalam Aku dan Aku di dalam Bapa", dijelaskan Rakhmat dengan cara melihat konteks ayat-ayat tersebut. Yohanes 10:30 adalah jawaban Yesus terhadap pertanyaan atas kemesiasanNya ("Jikalau Engkau Mesias, katakanlah kepada kami”, 10:24), demikian juga Yoh.10:38d diajukan sebagai jawaban atas pertanyaan mengenai hubunganNya dengan Allah (10:33). Sebelum Ia sampai pada perkataan di dalam 10:30 itu, Yesus menunjuk pada "pekerjaan-pekerjaan" yang dilakukanNya dalam nama Bapa (ay.21\&25); lalu kepada diriNya sebagai gembala (ay.2627; 10:1-21). Pekerjaan-pekerjaan dan perananNya selaku gembala dikuatkan melalui penekanan-penekanan yang terdapat di dalam ayat 28 dan 29. Dengan menyebut diriNya "Gembala" yang memberikan "hidup kekal" (ayat 28), Yesus menyatakan bahwa kehadiranNya adalah kehadiran kuasa Allah yang mendatangkan keselamatan dan pemeliharaan, dan itulah pekerjaan-pekerjaanNya. Ayat $28 \& 29$ memuat pernyataan yang sama: tidak seorangpun dapat merebut domba baik dari tangan Yesus maupun dari tangan Bapa. Dari acuan kepada Yesus dan Bapa pada ayat 28 \& 29, dapat disimpulkan bahwa Yesus memiliki kuasa yang sama dengan kuasa Bapa; dan karena itu tidak mengejutkan bahwa apabila dalam Yohanes 10:30, Yesus menyatakan bahwa Dia dan Bapa satu adanya. Ini berarti bahwa kesatuan Yesus dengan Bapa adalah kesatuan dalam kuasa yang tampak di dalam pekerjaan-pekerjaan-Nya untuk memelihara dan menjaga domba-dombaNya.(Rakhmat 1996)

Selain penjelasan dalam ayat-ayat tersebut, Rakhmat juga mengangkat Yohanes 10:29, yang berisikan perkataan Yesus bahwa Bapa yang memberikan domba-domba kepada Yesus, dan bahwa Bapa "lebih besar dari siapapun" (14:28). Karena kuasa Bapa melebihi segalanya, maka seorangpun tidak dapat merebut domba-domba dari tangan Bapa. Yesus bekerja untuk dan dalam kuasa Bapa, karena itu kuasa Bapa juga berada di dalam pekerjaanpekerjaan Yesus dan menyertaiNya $(5: 27 ; 8: 16,29 ; 17: 2)$. Kuasa Bapa yang ada di dalam pekerjaan-pekerjaan Yesus inilah yang menyebabkan Yesus memiliki kuasa untuk 
memberikan hidup kekal kepada domba-dombaNya serta memelihara mereka. Dengan kata lain, meskipun Yesus memiliki kuasa yang sama dengan kuasa Bapa, tetap dinyatakan bahwa hubungan Yesus sebagai Anak Manusia dengan Bapa adalah hubungan ketergantungan: tanpa Ia bergantung kepada dan menerima kuasa dari Bapa, Yesus tidak memiliki kuasa apapun. Rakhmat menyimpulkan bagian ini dengan berkata bahwa kesatuan Yesus dengan kuasa Allah, bukanlah kesatuan hakikat sepenuh-penuhnya dan dengan demikian tidak bermaksud untuk menyatakan bahwa Anak Manusia adalah Allah; tetapi menegaskan bahwa di dalam ketergantunganNya kepada sang Bapa, Anak Manusia menerima kuasa ilahi atau mendapat bagian di dalam kuasa Bapa yang membuat Ia berkiprah seturut dengan kehendak dan di dalam kuasa Bapa yang mengutusNya yang lebih besar daripadaNya.(Rakhmat 1996)

\section{b. Pandangan Tom Jacobs Bahwa Yesus Kristus Adalah Ciptaan Allah}

Tom Jacobs, seorang teolog pluralis Katolik Indonesia berusaha "merumuskan" kembali ajaran tentang Yesus Kristus yang dianut oleh Kekristenan Ortodoks yang meyakini bahwa Yesus Kristus, sebagai Pribadi Kedua Allah Tritunggal yang berinkarnasi itu adalah Allah. Dalam bukunya yang berjudul: "Imanuel, Perubahan Dalam Perumusan Iman Akan Yesus Kristus," dia menyimpulkan bahwa Yesus tidak sama dengan Bapa, Dia tidak setara dengan Bapa dan Bapa saja satu-satunya Allah yang benar.

Untuk sampai pada kesimpulan itu, Jacobs merumuskan pokok pikirannya dalam sub bab "Imanuel II", suatu intisari ajaran yang dia tegaskan dalam buku ini. Jacobs mengemukakan lima misteri penyingkapan ilahi Allah bagi manusia. Tiga dari lima misteri tersebut berbicara mengenai Allah Bapa dan Yesus Kristus, sementara dua yang terakhir tentang Roh Kudus dan iman dalam manusia. Yang akan dibahas adalah tiga misteri yang pertama.

Misteri pertama: Tanpa ikatan Allah beserta kita. Jacobs mengemukakan perbedaan antara Allah dan makhluk ciptaan yang bertolak dari tradisi Yahudi-Kristiani. Dia mengutip Keluaran 33:20 yang menegaskan perbedaan itu dalam peristiwa Musa di gunung Sinai yang tidak boleh memandang wajah Allah. Selanjutnya penegasannya datang dari Konsili Lateran IV (1215) yang mengajarkan: "Betapa besar kesamaan yang dilihat antara Pencipta dan ciptaanNya, perbedaannya selalu lebih besar." Selanjutnya dogma Kalcedon menguatkan hal itu dengan pernyataan bahwa "Tuhan, Anak Tunggal, diakui dalam dua kodrat tak tercampur, tak berubah, tak terbagi.”(Jacobs 2000) Kemudian Jacobs mengemukakan:

Juga dalam Kristus ditolak segala identitas antara keallahan dan kemanusiaan. Kedua ini dibedakan secara total. Allah tetap Allah, dan manusia tetap makhlukciptaan, juga dalam Kristus. Kristus bukan Allah-manusia dalam arti setengah Allah, setengah manusia. Bahkan kemanusiaan Kristus juga tidak punya ciri ilahi. ... Kristus sungguh manusia dengan segala pengalaman dan penderitaan sebagai manusia. Maka kemanusiaanNya juga tidak boleh dipandang sebagai suatu "bagian" saja. Seluruhnya dan seutuhnya manusia seperti kita.(Jacobs 2000)

Selanjutnya Jacobs membedakan antara soteriologi yaitu teologi mengenai karya penyelamatan Allah, dan kyriologi yaitu teologi mengenai pribadi Kristus. Menurut Jacobs, tradisi teologi Yunani sampai kini yang menjadi pemahaman teologi Kristen ortodoks, mencampurkan antara soteriologi dengan kyriologi. Maksudnya bahwa karya keselamatan Allah sekarang ini dilihat dari sudut kyriologi yaitu keselamatan diletakkan dalam pribadi Kristus, sedangkan jika dilihat dari sudut Allah gambarannya menjadi lain, di mana tetap ada perbedaan antara pribadi Allah dan pribadi manusia. Hubungan antara soteriologi dan kyriologi menurut Jacobs adalah tindakan penyelamatan Allah, yang darinya sendiri bersifat 
kreatif: Tuhan menciptakan manusia dalam relasi dengan diriNya, Allah menghubungi manusia, dan menyatakan diri dalam manusia Yesus Kristus.(Jacobs 2000)

Beranjak dari misteri pertama tersebut, Jacobs mengemukakan misteri kedua: Karya penciptaan dan karya penyelamatan. Jacobs menegaskan bahwa: "penciptaan adalah tindakan bebas Allah... dari dirinya sendiri ciptaan tidak punya apa-apa." Selanjutnya Jacobs menambahkan bahwa: "Tuhan menciptakan yang bukan Allah, supaya dapat memberikan diri. Bahkan kedua ini tidak boleh dipisahkan: Tuhan menciptakan yang bukan Allah, dengan memberikan diri. Tujuan karya penciptaan adalah karya penyelamatan.(Jacobs 2000)

Pernyataan Jacobs tersebut penting untuk datang pada satu penegasan bahwa Yesus Kristus adalah salah satu ciptaan supaya Allah bisa memberikan diriNya kepada manusia, seperti pernyataannya: "Kristus diciptakan bertujuan pertemuan dengan Allah. Bahkan Kristus adalah 'yang sulung dari segala yang diciptakan ... .' Maka Kristus diciptakan Allah tertuju kepada diri-Nya, sebagai dasar bagi kesatuan semua orang dengan Allah. Kristus diciptakan dalam penyerahan total kepada Allah. ... Sebagai Anak Allah Ia tidak lepas dari manusia yang lain, melainkan adalah 'yang sulung', karena Allah menghendaki-Nya sebagai dasar karya penyelamatan-Nya. ... Penciptaan Kristus tidak hanya sama dengan pemberian diri Allah, tetapi merupakan dasar dan awal pemberian diri Allah kepada manusia semua. Tetapi justru sebagai Pencipta, berarti sebagai Allah, Allah tetap terbedakan dari ciptaanNya, juga dari Kristus. Kristus seluruhnya terarah kepada Allah, tetapi tidak identik dengan Allah.(Jacobs 2000)

Jacobs menyangkal keallahan Yesus Kristus juga dengan permainan bahasa yang melihat dari sudut pandang manusia. Kata "Tuhan" menurut Jacobs berbeda dengan kata "Allah". Tuhan dipakai untuk Yesus dan Allah untuk Bapa dengan merujuk pada 1 Kor.8:6 dan 2 Kor.11:31. Jacobs menambahkan beberapa ayat yang mendukung argumennya antara lain dalam Yohanes 1:1 dan 18 tidak ditemukan bahwa Yesus disebut Allah tetapi Firman. Yoh.20:28 yang adalah ungkapan pengakuan Tomas, "Ya Tuhanku dan Allahku" hanya mau menonjolkan kesatuan Yesus dengan Allah.(Jacobs 2000)

Yang terakhir, Jacobs mengakhiri pembahasan misteri kedua ini menegaskan lagi: "Harus membedakan antara karya keselamatan Allah, mulai dengan karya penciptaan, dan manusia Yesus. Yesus adalah seorang manusia yang dari semula secara total terarahkan kepada Allah".(Jacobs 2000)

Misteri Ketiga: Allah Tritunggal. Pada bagian ini, Jacobs berusaha menjelaskan konsep Allah Tritunggal menurut versinya. Dia memulai dengan mengangkat Kisah Para Rasul pasal 7 tentang khotbah Stefanus. Menurutnya ayat 55 dalam pasal 7 ini merupakan teologi Trinitas yang paling singkat. Jacobs menegaskan: "Allah sendiri tidak kelihatan, dan memang tidak dapat dilihat, hanya disadari kehadiran-Nya. Roh Kudus pun tidak kelihatan, merupakan daya kekuatan dalam Stephanus sendiri. Tetapi Yesus kelihatan, 'di sebelah kanan Allah'. Allah tetap "bersemayam dalam terang yang tak terhampiri" (1 Tim.6:16). ... Yesus sebagai Firman Allah” (Jacobs 2000).

Bagaimana teologi Trinitas yang dirumuskan oleh Bapa-bapa Gereja di abad permulaan yang sampai kini menjadi ajaran Kristen Ortodoks? Menurut Jacobs, teologi tentang Trinitas yang ada adalah hasil pertemuan Kristen dengan ajaran-ajaran sesat. Bahwa "pengertian mengenai Allah dikembangkan berkonfrontasi dengan ajaran-ajaran yang sesat, maka teologi tentang Trinitas lama-kelamaan dirumuskan dalam kategori pemikiran yang bukan lagi berasal dari kitab suci”.(Jacobs 2000)

Menurut Jacobs, hubungan Yesus Kristus dengan Bapa bukan seperti yang dirumuskan oleh Bapa-bapa Gereja mula-mula, yang perumusannya dipengaruhi oleh situasi berkembangnya ajaran-ajaran sesat. Jacobs menyatakan bahwa hubungan Allah (Bapa) dengan Yesus Kristus adalah sebagai berikut: "Allah masuk ke dalam dunia manusia dengan 
mengadakan manusia Yesus sebagai anakNya, yang seluruhnya terarah kepada Allah sebagai BapaNya. Namun semua ini adalah tindakan Allah dan rencana Allah, yang dari awal mula sudah ada dalam diri Allah. Dalam arti itulah Yesus sebagai Firman sudah ada pada Allah sebelum segala abad. Maka karena kedudukanNya yang unik dalam karya penyelamatan Allah, Kristus juga bukan hanya seorang nabi, tetapi disebut Almasih. Dengan sebutan itu ditunjuk bahwa Ia bukan hanya pewarta karya Allah, tetapi pelaksananya. Allah sungguh bertindak dalam Yesus, dan membuat Yesus menjadi alatNya, menciptakanNya sebagai penyelamat. Dalam arti itu Ia Anak Allah. Kitab suci memberikan julukan ini kepadaNya sebagai gelar kehormatan untuk mengungkapkan kasih Allah yang istimewa kepadaNya.(Jacobs 2000)

Yesus Kristus bukan salah satu dari tiga pribadi Allah dalam Trinitas yang setara dengan Allah Bapa, tetapi Ia hanya suatu pribadi dimana Allah Bapa bertindak di dalamnya. Yesus Kristus hanyalah ciptaan Allah untuk tugas penyelamatan yang dirancangkan Allah Bapa.

\section{Analisa Terhadap Pandangan Subordinasionisme}

Konsep subordinasi Anak adalah sebuah doktrin yang sebenarnya sudah ada sejak gereja mula-mula. Pernyataan yang berasal dari teolog abad ke-20 berikut ini, mengekspresikan dengan baik arti doktrin tersebut dan kesanggupannya menembus sejarah Gereja: "From the second century onward a concept of the Son's subordination to the Father has been combined with a concept of the full equality among the Three. Each is seen to be fully, equally and eternally divine, although in their relationship to one another, the Father assumes supremacy and the others a subordinate role"(Cottrel 1987). Munculnya konsep subordinasi Anak terhadap Bapa terkait erat dengan perkembangan perumusan ajaran Allah Tritunggal atau Trinitas.

Konsep Allah Tritunggal pada Tertullianus, Origenes dan kemudian Arius merupakan bibit yang disemai bagi kaum pluralis dalam mengajukan konsep subordinasi Allah Tritunggalnya. Tertullianus dalam suatu tulisannya misalnya menegaskan Allah Bapa, Allah Anak dan Roh Kudus menyatu di dalam substansinya. Namun kesatuan substansi Allah ini terdistribusi ke dalam tiga pribadi, yaitu pribadi Allah Bapa, pribadi Yesus Kristus dan pribadi Roh Kudus. Tiga pribadi ini bukanlah tiga kondisi, tetapi tiga di dalam tingkatan, bukan dalam substansi tapi dalam bentuk, bukan dalam kuasa, tetapi aspek-aspeknya. Namun, Allah adalah satu dalam substansi, dalam kondisi, dalam kuasa, dan dalam kekuasaan, sampai Ia disebut sebagai Satu Allah. Origenes menegaskan bahwa Anak secara kekal dihasilkan atau diperanakkan oleh Bapa. Inilah suatu proses atau hubungan yang kekal. Ini bukan suatu peristiwa tertentu, bukan pula sesuatu yang terjadi jutaan tahun yang lalu, tetapi ia adalah sesuatu yang senantiasa terjadi secara kekal. Trinitas itu "bertingkat," yaitu Bapa lebih besar daripada Anak yang lebih besar daripada Roh Kudus. Hanya Bapa adalah Allah sejati. Anak Allah sama dengan Allah Bapa, hanya pada tingkat yang lebih rendah. Jikalau Bapa adalah Allah, maka orang bisa juga mengatakan Anak adalah Allah. Dengan demikian terlihat bahwa Ketritunggalan Origenes adalah Ketritunggalan bertingkat tiga, Allah pada tiga tingkat yang berbeda-beda.

Menanggapi tulisan Rakhmat, sebenarnya bagi kalangan Kristen, logos dalam Injil Yohanes ini adalah sang Firman, yaitu pribadi kedua Allah Tritunggal yang melakukan tindakan opera ad extra (tindakan yang berhubungan dengan ciptaan, yakni menyelamatkan umat manusia). Sang Firman setara baik dari segi esensi maupun derajatNya dengan sang Bapa. Tindakan sang Firman yang datang ke dalam kondisi umat manusia (untuk melaksanakan fungsiNya) tidak menyebabkan Ia menjadi lebih rendah kedudukanNya dari Allah Bapa. 
Kesimpulan subordinasionisme dalam Injil Yohanes sebagaimana dikemukakan oleh Rakhmat sebenarnya dipengaruhi oleh sistim hermeneutika yang ia pergunakan. Rakhmat telah mengajukan presuposisinya terlebih dahulu pada teks yang akan ia tafsir. Presuposisi Rakhmat adalah bahwa Injil Yohanes lahir dari suatu mazhab yang mempertahankan monoteisme Yahudi. Kemudian presuposisinya berkembang dengan pertanyaan, bagaimana mazhab ini tetap mempertahankan monoteisme sementara dalam pandangan mazhab ini, ada "tokoh sorgawi" lain yang datang ke dalam dunia dan disamakan dengan Allah sendiri.

Sistim hermeneutika semacam ini dikenal dengan "pre-understanding". Akar sistim hermeneutika pre-understanding ditegaskan Robert L. Thomas, sebenarnya adalah new subjectivism dan relativism (Thomas 1992). Akar dari new subjectivism dan relativism itu sendiri berasal dari pengajaran Friedrich Schleiermacher, Rudolph Bultmann dan Immanuel Kant, tentang pengajaran eksistensi dunia dari dua dunia realitas. Konsep ini kemudian diadopsi oleh para theolog yang mengemukakan konsep pre-understanding atau hermeneutika self-awareness (mengetahui sendiri).

Mengenai penegasan Rakhmat bahwa Injil Yohanes lahir dari suatu mazhab yang mempertahankan monotesime Yahudi memang benar, akan tetapi kemudian Rakhmat membangun presuposisinya yang keliru dari kenyataan historis yang tidak lengkap. Jey J. Kanagaraj mengemukakan latar belakang historis yang memberi alasan bagi Yohanes untuk menulis Injil ini sebagai berikut:

John wrote his Gospel at a time when severe efforts were being undertaken to revive the religious life of Jews after the fall of Jerusalem in AD 70. Since the Temple had been destroyed, people thought that God was far away from them. The Jewish rabbis like Yohanan ben Zakkai began to concentrate more on studying and interpreting the Torah in order to bring theophany down to earth. Belief in angels as mediators between the transcendent God and human beings became more important. ... That is, rabbis and the common people had great interest in ascending to heaven to see God in his glory seated on the throne and in gaining heavenly knowledge through visions based on Ezekiel 1, Isaiah 6, and Daniel 7. John addresses such interest by showing that God's kingly glory can be seen here on earth in Jesus, the Son of Man and Son of God $(1: 18,51 ; 3: 13$; $12: 41 ; 14: 9-11)$. ... For the Jews considered the religious life and worship of Christians as a threat to the monotheistic faith of Judaism because of the Christians' claim to the divine revelation in Jesus Christ. Christians were accused of believing in two divine powers in heaven. Now we can understand why John gives evidence for his monotheistic faith in his Gospel"(Kanakaraj, Jey J. \& Kemp 2000)

Kanagaraj menyatakan bahwa Yohanes menulis Injilnya pada saat keadaan semangat keagamaan dibangkitkan kembali oleh orang-orang Yahudi setelah peristiwa jatuhnya Yerusalem dan penghancuran Bait Allah. Dalam situasi seperti ini, para nabi Yahudi dan orang-orang Yahudi umumnya menganggap Allah sangat jauh dari mereka, sehingga mereka mempelajari Taurat dengan teliti dengan harapan adanya peristiwa-peristiwa teofani sebagaimana yang pernah terjadi pada masa PL. Mereka menaruh rasa percaya akan malaikat-malaikat sebagai perantara Allah yang transenden dan manusia, atau berdasarkan Yehezkiel 1, Yesaya 6, dan Daniel 7, mereka berharap akan mengalami pengalaman seperti pengalaman Yehezkiel, Yesaya dan Daniel, dapat menyaksikan Allah dalam kemuliaanNya di surga. Pada situasi keagamaan seperti inilah Yohanes menulis Injilnya, tentunya berdasarkan inspirasi Roh Kudus, bahwa Allah yang transenden itu sekarang dapat 
disaksikan di bumi melalui Yesus Kristus sang Anak Allah, tetapi dengan pemahaman Allah Tritunggal yang menegaskan posisi iman monoteis dari Yohanes sang penulis Injil.

Ioanes Rakhmat keliru apabila menganggap bahwa Yohanes menulis Injilnya berdasarkan ajaran yang sementara berlaku di kalangan rabi Yahudi dan orang-orang Yahudi pada saat itu. Inilah bentuk hermeneutika pre-understanding yang diterapkan Rakhmat pada teks ini.

Menurut penulis, Ioanes Rakhmat adalah penganut "Yesus sejarah" dengan komentarnya tentang Yesus dalam Injil-injil adalah ciptaan penulis bukan historis, dan ia pun membedakan ucapan asli Tuhan Yesus dan produk para penulis sebagaimana kesimpulan kelompok Jesus Seminar: Yesus tidak pernah menuntut diri-Nya disebut dan diakui sebagai Mesias.

Konsep tentang perbedaan Yesus sejarah dengan Yesus yang ditulis para penulis Injil sebenarnya berawal dari zaman rasional. Banyak sarjana Alkitab dan teolog yang profesional sebelumnya tidak pernah mempermasalahkan Injil, bahkan menjadi pembela Injil, memasuki zaman rasional justru menjadi pengkritik Injil. Mengapa hal ini terjadi? Karena rasionalitas mensyaratkan (tanpa pembuktian) bahwa kejadian supranatural tidak pernah terjadi dan bahwa pikiran manusia berfungsi secara maksimal terlepas dari pengakuan akan suatu wahyu ilahi. Dengan kata lain, mereka mengadopsi konsep otonomi manusia(Frame 2000).

Menanggapi hal ini, selanjutnya Frame mengemukakan posisi lemah dari para theolog liberal yang meragukan apa yang Alkitab nyatakan: "Tidak mungkin ada keberatan untuk menunjukkan data tambahan di luar Alkitab..., sejauh data-data tersebut tidak disajikan sebagai 'Firman Allah' pada tingkat yang sama dengan Alkitab.'(Frame 2000) Setelah melewati beberapa waktu, terlihat adanya ambiguitas dalam pemikiran para theolog liberal yang mengemukakan konsep ini, seperti yang Frame tuliskan: "Kelihatannya menjadi suatu kecenderungan dalam studi Alkitab ... bagi sarjana-sarjana liberal untuk sampai pada kesimpulan-kesimpulan yang lebih dalam dan lebih konservatif tentang penanggalan, keotentikan, dan historisitas dari kitab-kitab dalam Alkitab. Walaupun para sarjana liberal dalam awal abad kesembilan belas terus-menerus menolak akurasi dari semua narasi Alkitab berhubungan dengan kejadian-kejadian yang tertuju kepada Musa dan menekankan bahwa banyak dari kitab-kitab Perjanjian Baru berasal dari pertengahan abad kedua, bukti arkeologi dan dokumenter memaksa banyak sarjana untuk menerima historisitas paling tidak dari latar belakang laporan-laporan patriakhal. Dan sekarang semua kitab-kitab Perjanjian Baru diakui secara umum berasal dari abad pertama. Menariknya, beberapa dari para sarjana yang paling radikal dalam teologi mereka (Adolf Harnack, John A.T. Robinson) adalah yang paling konservatif dalam penilaian-penilaian historis mereka. Robinson, yang mengemukakan sebuah theologi yang terang-terangan tidak Alkitabiah dalam bukunya ... Honest to God, kembali dalam sebuah buku yang belakangan mengklaim bahwa dokumen-dokumen Perjanjian Baru mungkin semuanya ditulis sebelum 70 A.D”.(Frame 2000). Dari tulisan Frame ini nyata bahwa konsep para theolog liberal yang menjadi dasar para theolog pluralis untuk menyusun kristologinya tidak mendasar sama-sekali.

Selanjutnya, salah satu persoalan kristologi modern ialah berkenaan dengan persoalan relasi antara sejarah Yesus (peristiwa Yesus) dengan waktu penulisan dan isi tulisan Injilinjil oleh para penulis. Lumintang mengutip Bruce mengemukakan bahwa: "Para theolog historis kritis, dengan metode kritik Alkitabnya, di antaranya kritik redaksi, mengadakan penelitian secara kritis mengenai peredaksian kitab-kitab Injil, dan membandingkan serta menemukan perbedaan-perbedaan antar Injil untuk membuktikan bahwa tulisan tersebut merupakan tafsiran ulang dari para penulis/penginjil untuk dikonsumsikan kepada konteks orang Kristen pada waktu itu, yang jelas berbeda dengan konteks sekarang ini. ... ternyata kritik redaksi ini, tidak hanya melihat bahwa tulisan Injil merupakan hasil penafsiran ulang 
para penginjil, melainkan juga merupakan rumusan theologis dari penginjil yang notabene adalah theolog, dan ungkapan iman dari penulis, yang notabene adalah orang beriman. Dari pendekatan seperti ini, maka disimpulkan bahwa tulisan-tulisan Injil bukanlah tulisan historis, melainkan tulisan theologis dan ungkapan iman dari para penulis Injil".(Stevri I. Lumintang 2000)

Kritik tersebut menghasilkan sebuah kesimpulan yang mendasar bahwa pesan Injil (kerygma) gereja mula-mula tersebut tidak berhubungan dengan peristiwa Yesus, karena tulisan Injil tersebut lahir dari penafsiran (theologia) para murid, yang tidak berangkat dari sejarah melainkan dari iman kepada sejarah. Dengan kata lain, para theolog historis kritis hendak mengemukakan bahwa Yesus yang tertulis dalam Injil bukanlah Yesus sejarah, melainkan Yesus kepercayaan. Konsep seperti ini terlihat dalam tulisan Tom Jacobs yang menyatakan bahwa tulisan para murid (Injil) adalah tulisan-tulisan yang bersifat kyriologis (memuliakan Kristus sebagai utusan Allah di dunia yang dikenal para murid secara langsung), daripada soteriologis (mengedepankan karya keselamatan yang Allah sendiri lakukan). Jacobs mengemukakan: "Dalam praktek sering dilupakan, bahwa "sesudah kenaikan Tuhan para Rasul meneruskan apa yang dikatakan dan dijalankan oleh Yesus sendiri, dengan pengertian yang lebih penuh, yang mereka peroleh karena dididik oleh peristiwa-peristiwa mulia Kristus". Injil-injil bukanlah laporan, melainkan pewartaan, yakni pewartaan yang berpangkal pada "peristiwa-peristiwa mulia Kristus". Maka tidak dapat tidak Injil musti bersifat kyriologis. ... Bahwa Injil secara menyeluruh dan penuh memusatkan perhatian pada diri Yesus, tidaklah terlalu mengherankan. Semua injil adalah kisah mengenai segala sesuatu yang dikerjakan dan diajarkan Yesus, sebab Yesus memang diakui sebagai titik temu dengan Allah. Oleh karena itu, injil tidak boleh dipandang sebagai semacam biografi saja... Injil mau memberi kesaksian mengenai Yesus sebagai penyelamat. Justru di sini tampak sifat kyriologisnya, sebab biasanya Allahlah yang disebut 'Juruselamat kita"” (Jacobs 2000)

Kaum historis kritis kemudian memajukan suatu bentuk kristologi yang berangkat dari Yesus sejarah. Mereka mengajarkan suatu Kristologi yang melihat Yesus sejak inkarnasiNya, bukanlah sejak pra-inkarnasiNya (atau pra-eksistensiNya). Lumintang menuliskan: "Kristologi kaum historis kritis ialah kristologi yang berdasarkan pada Yesus sejarah, yaitu kristologi yang berangkat dari fakta-fakta sejarah mengenai Yesus, bukan berdasarkan uraian theologis dan keyakinan para penulis Injil seperti kitab yang dipegang oleh orang Kristen sekarang ini. Dengan kata lain mereka tidak mengakui Alkitab adalah berdasarkan fakta sejarah, dan tidak mengakui relevansi Alkitab untuk masa kini”" (Stevri I. Lumintang 2000).

Hal inilah yang menyebabkan pengakuan para murid dalam Injil, juga pengakuan dalam tulisan-tulisan Paulus dan tulisan-tulisan yang lain yang terdapat dalam Alkitab bahwa Yesus adalah Tuhan ditanggapi skeptis oleh para teolog pluralis karena teolog historis kritis adalah sahabat dekat para teolog pluralis.

\section{SIMPULAN}

Bagi kaum pluralis, adalah tidak relevan untuk membicarakan benar salahnya suatu agama, karena masalah agama adalah masalah pribadi. Pluralisme menolak semua klaim agama yang bersifat absolut dan mutlak, unik, normatif, eksklusif atau final(itas). Pluralisme bukan sekedar konsep sosiologis, melainkan lebih merupakan "doktrin" teologis yang didasarkan pada relativisme yang bersumber pada pandangan dunia atomis (individualis Barat), maupun pandangan oseanis (Hindu), sedangkan keunikan dan finalitas Kristus dianggap sebagai sebuah mitos yang perlu ditinggalkan.

Subordinasionisme dalam Allah Tritunggal sebenarnya tidak ada. Perbedaan yang terlihat dalam Allah Tritunggal sebenarnya hanya menyangkut fungsi tiga pribadi Allah yang 
berbeda-beda dalam hubungan dengan ciptaan (opera ad extra). Konsep subordinasi yang dikemukakan kaum pluralis sebenarnya hanyalah upaya untuk "menganulir" ajaran Kristen bahwa Allah Tritunggal yang esa itu terdiri dari tiga pribadi (hypostasis), yakni Allah Bapa, Allah Anak (yaitu Yesus Kristus), dan Allah Roh Kudus. Karena apabila Yesus Kristus dapat dibuktikan bukan Allah, maka itu berarti ajaran pluralisme mengenai adanya kebenaran dalam semua agama adalah benar, dan sebaliknya ajaran Kristen (ortodoksi) keliru. Contoh pandangan pluralisme yang diangkat dari Injil Yohanes, setelah ditelusuri, ternyata berasal dari presuposisi dan bentuk hermeneutik yang dipengaruhi oleh konsep filsafat manusia, dan bukan apa yang Alkitab ajarkan.

\section{DAFTAR PUSTAKA}

Berkhof, Louis. 2001. Teologi Sistematika: Doktrin Allah. Jakarta: Percetakan Timur Agung Lembaga Reformed Injili Indonesia.

Carson, D.A. 1996. The Gagging of God, Christianity Confronts Pluralism. Leicester, England: Apollos.

Cottrel, Jack. 1987. What the Bible Says About God the Redeemer. England: College Press. Frame, John M. 2000. Apologetika Bagi Kemuliaan Allah. Surabaya: Momentum.

Hick, John and Knitter, Paul F. (eds.). 1992. The Myth of Christian Uniqueness: Toward a Pluralistic Theology of Religions. USA: Orbis Book.

Jacobs, Tom. 2000. Imanuel, Perubahan Dalam Perumusan Iman Akan Yesus Kristus. Yogyakarta: Kanisius.

Kanakaraj, Jey J. \& Kemp, Ian S. 2000. Gospel of John. India: Theological Book Trust of Bangalore.

Millard J. Erickson. 1995. The Word Became Flesh. Michigan: Baker Books.

Pannikar, Raiymundo. 2001. "Sungai Yordan, Tiber Dan Gangga". Mitos Keunikan Agama Kristen, England: College Press, 124.

Rakhmat, I. 1996. 'Theologia Religionum." In Fundamentalisme, Agama-Agama Dan Teknologi, Jakarta: BPK Gunung Mulia, 60.

Sinaga, Martin L. 1999. "Meretas Jalan Theologia Agama-Agama Di Indonesia”, Dalam Tim Balitbang PGI (Peny.), Meretas Jalan Theologia Agama-Agama Di Indonesia. Jakarta: BPK. Gunung Mulia.

Stevri I. Lumintang. 2000. Teologi Abu-Abu, Pluralisme Iman. Batu: Departemen Literatur YPPII.

Sumartana, Th. 1999. "Theologia Religionum" Dalam Tim Balitbang PGI (Peny.), Meretas Jalan Theologia Agama-Agama Di Indonesia, Jakarta: BPK. Gunung Mulia, 24.

Thomas, Robert L. 1992. "Current Hermeneutical Trends: Toward Explanation or Obfuscation.” Journal Evangelical Theological Society 39((2)): 245-57, 249-250.

Walter A. Elwell (ed.). 1997. Evangelical Dictionary of Theology. Grand Rapids, Michigan: Baker Book House.

Yewangoe, A. A. 2001. Agama Dan Kerukunan. Jakarta: BPK Gunung Mulia. 